\title{
On Creativity, Inutility and Play
}

\author{
Klára Pirklová \\ Charles University in Prague, Czech Republic \\ E-mail address: klara.pirklova@gmail.cz
}

ARTICLE INFO

\section{Keywords:}

Creativity

Paideia

Pragma

Play

Socrates

Pippi Longstocking

\section{Article history:}

Received 17 March 2017

Received in revised form 28 August 2017

Accepted 10 September 2017

ISSN: 2354-0036

DOI: $10.1515 /$ ctra-2017-0018

\section{A B S T R A C T}

The article deals with the topic of play as the background for creativity. Methodologically, the study is based on a phenomenological-hermeneutical approach. This means we do not base our questions on predefined terms, but rather aim to search for them. Thus, in pursuit of questioning the phenomenon of creativity, we explore other phenomena - play, education (paideia) and utility (pragma). To picture the relationships between these phenomena we borrow two symbolic figures - Socrates and Pippi Longstocking. Socrates appears here as the symbol of wondering and the antidote to all false sophistication (and thus true education), and Pippi as the exemplar par excellence of free, joyous and thoroughly inutile play. In the article we aim to expose the inutile and creative character of play as its greatest benefit. Our line of questioning follows the traditions of Czech philosophy of education, represented by Jan Patočka.

\section{INTRODUCTION}

Contemporary society glorifies utility. We experience this every day in different spheres of life. We are encouraged to gain IT and financial literacy, learn the English language, work hard and relax efficiently to be able to work even harder and when everything fails, get newly motivated by life coaches. There is an apparent pressure on performance and utility (in ancient Greek: pragma).

Human creativity refers to performance, too. But this kind of performance balances utility with inutility. Being creative means being original, non-conformist, being a sort of risk-taker (Amabile, 1996). Being creative in this sense means moving outside the boarders of what is merely useful, merely conveniant and merely satisfactory.

In our article we aim to bring to light the questions of inutility in education and play as the background for creativity. In the first part of the article, we look back at the basics 
of European education or rather the foundations on which European civilization grew through centuries, beginning in ancient Greece with Socrates. The second part tackles the phenomena of wondering and irony as (1) the core upon which our civilization grew, as well as (2) the moment of realization that happens again and again as a subtle but still important turn in one's soul. We portray two masters of irony here. Socrates and a famous figure from European literature for children, the fearless and flippant, yet kind and generous Pippi Longstocking. A symbol of free, thoroughly inutile and freshly creative play. In the third part, we get more profound in thinking about play as a philosophical phenomenon and look closely at the theories of play expounded by its classical theorist Huizinga, as well as the philosophers Gadamer and Fink.

\section{PLATO'S PAIDEIA}

In considering modern education, on the one hand we speak about it as a product of the modern age, on the other hand, the idea of education itself is an ancient concept. As Patočka (1996, 1999, 2002) shows, in Plato's dialogues there appears the word paideia, that is used when a human soul takes a step from the sphere of common belief (gr. doxa) to the sphere of true knowledge (gr. episteme). In Greek the term paideia could be defined as epimeleia peri tes psyche, translated into English as care for the soul. In Patočka's interpretation, paideia is a move toward a higher level of life that raises a human being from a mere biological level. In other words, it is a turn (gr. metanoia) that makes human a true human. In that sense, Patočka considers paideia the most important term of Greek philosophy, thus its touchstone and the foundation of European civilization as such.

To understand the concept of paideia in a wider perspective, we must not omit to mention the sophists and Socrates. The sophists were the first political movement in European history, back in the 6th century BC, who discovered the power of discourse, relativization and rhetoric's. The movement gained approval as in Greek polis politics became a popular public matter (gr. res publica). The streets of ancient polis, like Athens, became busy places for holding discussions, lecturing, teaching etc. And in the midst of all the business and hectic life, as a reaction to it, there appeared Socrates, a figure who simply began questioning it all. It was a simple antidote to all the sophistication. Yet, not an easy and effortless one. Socrates developed a rigorous method of dialectic that enabled serious philosophical reflection of opinions, values and ideas. It required strict selfdiscipline of mind, or as Chvatík (2011) says, it required strict care for the soul, paideia.

Plato tried to illustrate the movement of paideia in his Parable of the Cave. He illustrates a human soul as a prisoner in the cave. The prisoner is tied to the wall, forced 
to look in just one direction. This is his only perspective on the world, on his own life. Then suddenly, somebody comes and forces the prisoner to leave the cave. The prisoner is literally dragged out of the cave up to the sunlight. With the parable Plato aims to illustrate that the human soul may be cultivated, cared for and educated by being freed from the cave. The cave in Plato's parable is the symbol for common belief, passed on ideas, taught values, unreflected tradition etc.

\section{ÁSCHOLÍA AND SCHOLÉ}

When we talk about the ancient concept of paideia as the foundation of European civilization, there is one important aspect that needs to be emphasized: education can only begin when the student is released from everyday duties and obligations. Education starts only when there is a break from the everyday toil for basic needs. This break is a necessary condition for the care for the soul. In other words, the raising up from the cave cannot begin when the prisoner is tied to his everydayness. Or, the dialogue with Socrates cannot begin when one practices rhetorics. Thus, being freed from duties and obligations is not only about having free time, but more about having a free soul. As Pieper (1992) shows, here is linguistic evidence of this in ancient Greek as well as medieval Latin. Let us look at the etymology closer.

Ancient Greek distinguished between the words áscholía, which meant work, earning a livelihood, toil for basic needs (food, housing, shelter etc.) and between scholé, meaning leisure time, free time or holiday. Ascholia represents all the roles one has to play and all the goals that need to be achieved throughout our days. In the context of Socratic dialogue ascholia concerns unreflected experience and common belief. When we are busy with fulfilling practical tasks, we cannot begin serious reflection. It requires schólé of the soul. In most European languages schólé remains present as the expression for education (Engl. school, germ. Schule, sp. esquela, fr. école, cz. škola, pol. szkoła). Our own language reminds us that education requires schólé of the soul. Medieval Latin equivalents of the terms are negōtium that means business or affair and its opposite ottium meaning rest, respite or recovery. Besides, the word university, derived from in uno versum, meaning turning to the one, to the essential, also gives a certain clue about the initial direction of education in the European Middle Ages. From its beginning, the idea of university was far from the idea of collecting pieces of knowledge. As we can still see at Comenius (1966), it rather followed the ancient foundation of dragging oneself out of turmoil and confusion. Education was not a matter of everyday business, it was rather a movement of the soul (lat. conversio). 


\section{EDUCATION AFTER 'COGITO, ERGO SUM'}

As Palouš (2004) shows, for a long time in history, people actually did not need any schooling, it was not the necessity for everyone that we consider it to be today. Most people learned what they needed for their work life from their own parents and neighbours, schools were something of a privilege for noble men. Only the 18th century saw the establishment of secondary schools and it was no earlier than in the mid-19th century that the first primary schools came to existence. What caused this need is the shift in thinking that can be traced back to the mid-17th century and is marked by Descartes' "Cogito, ergo sum." The ancient and medieval world was different from ours. It was seen through the eyes of either ancient philosophers - observers of the harmonious order - or through the lens of medieval theologians, faithful seekers of God. Descartes' cogito meant a major shift. Human reason was acclaimed above all else and the world became an object. An object that could not only be observed and explored, but also measured, manipulated, utilized and even exploited. This new perspective led to the foundation of modern science and made the vast technological and industrial development of the 18th and 19th centuries possible. In a relatively short time the world became a large and complicated place to live in. It was not possible to hand down knowledge from teacher to student through tradition anymore. Human knowledge had to be collected into encyclopedias and textbooks. Schools slowly became institutions essential for a functioning society. Learning through tradition was replaced by learning through curriculum. Personal knowledge handed down from master to disciple was replaced by schoolbooks.

Thus as Palouš shows $(2004,2010)$, the focus on pragma in modern education, is not merely a matter of the past few decades. Rather, it has been a slow process that began with the end of the old thinking a few centuries ago. Modern thinking split education (paideia) and leisure time (schólé) into two different spheres. As Pieper (1992) believes, care for the soul turned into collecting information and utilizing knowledge. Leisure time turned into recovery from work for yet still other work. If it does not fulfill this expectation, it is considered idleness or even laziness. The moment of metanoia (lat. conversio) was lost from education completely, and is now only assigned to the sphere of religion. We have to admit that the baby was most definitely poured out with the bathwater.

\section{SOCRATIC WONDERING AS EXISTENTIAL MATTER}

When we look back at Socrates, the persona who stood at the beginning of it all, we may notice an important moment in his practice - that of wondering. He literally takes nothing for granted, putting question marks in front of all dead ends. He helps the citizens of Athens to realize their limitations. He teaches them to wonder. His docta ignorantia concerns not only the intellectual sphere of life, though. It tackles the whole existence of a human 
being. Socrates not only reveals to his fellow citizens their limits in knowledge, but above all, exposes the limitations of the actual state of their existence, their status quo. Thus, wondering, as Socrates described it, is an existential matter. Phileo sophia is an expression of such realization. Yes, I know I am not wise, but I love wisdom and want to follow its routes. The main stream, though, split into two different directions at the very beginning. Plato, Socrates' disciple, still covered both. Philosophy as the study of the general and fundamental nature of things on the one hand, as well as the change in the individual's soul, on the other. The first outlined designation requires general maturity in those who begin to philosophize. These are the citizens of Athens who appear in dialogues with Socrates. These are also the main figures of European philosophy who have appeared within the two-thousand-year stretch from ancient times. The second designation, though, requires simply a basic realization that my status quo is limited, that I am the prisoner in the cave. It is where education, as developed in European cultural space, is based, the concept introduced by Plato as paideia. As illustrated in his cave parable, its only condition is the soul freed from obligations, from the chains. It does not require any special or even extraordinary cognitive abilities. The complete opposite is true. Such love for wisdom is present as a possibility for all, all are invited to take part, even children. This is actually inscribed in the deepest roots of what European schooling is based upon. But, what if schools have forgotten their original foundations? Where can we find the ground that enables Socratic wondering over the simplest things?

\section{SOCRATES AND PIPPI LONGSTOCKING - WHAT THEY HAVE IN COMMON}

Gaare and Øystein (2004) quite provocatively compared Socrates to Pippi Longstocking. Pippi, the nine-year-old Swedish girl with her extraordinary appearance, supernatural power and lacking proper manners. A girl somewhat uneducated, pretty flippant and thoroughly honest. A girl whose only business is playing all day long. A girl strange in so many ways that even her small friends Tommy and Anika are often surprised by her behaviour. But they feel good in her company, as do generations of readers of The Adventures of Pippi Longstocking. Pippi is, as Socrates was, a thorn in the flesh to the citizens of her town. She frequently makes fun of their unreasonable attitudes. She despises conventions when facing injustice or dullness in the adult world. Her lightness of being is bothn contagious and disturbing at the same time. She is as ironic as Socrates. But Socrates used irony on purpose, his aim was to be a living conscience of his time. He was a philosopher. Pippi is just a 9-year-old girl with an exaggerated ability to play freely. She does not aim to do anything, she just does it. She simply immerses herself in her thoroughly unstructured, authority-less day and makes the best of it. Irony emerges when she encounters the hypocritical adult world. It appears while she bravely wonders 
over things, that for others are just so conventional that they are simply beyond questioning. For instance, she wonders why somebody should suffer from freckles. She wonders and at the same moment amazes everyone around her by her "simple-minded" questions. But while Socrates' questions were not simple-minded, they were just simple, so too is Pippi's behaviour. Lindgren did not create a simple-minded girl. She simply brought to light the untold through the irony of Pippi's maybe naïve, maybe unsophisticated, but truly authentic behaviour.

Children do not even know why they play, they simply do. They are not in pusuit of any wisdom through playing, it simply happens. As Opravilová (2007) shows: information we give to children in the process of education may be envisioned as a clue to solving a puzzle, though, it would not have any effect, if there was not space for the puzzling itself. The information needs to become part of our own inner motive. Only then can there really be room for the subtle but not unimportant change in one`s soul. Free inutile play, as we observe it within Pippi's adventures, creates such space. Space that in the face of all the utility around her, initiates some important and deep questioning without her actually setting out in pursuit of it. Our belief that education, philosophy and play are phenomena that share the same background needs some more profound thinking about play as a philosophical phenomenon, to which we now turn.

\section{PLAY TURNS ORDINARY INTO EXTRAORDINARY}

Although we can find different attitudes toward play, there would appear to be agreement on several significant characteristics regardless of the angle from which it is viewed. As described by Huizinga (1936) it is "a free activity existing quite consciously outside 'ordinary' life as being 'not serious', but at the same time absorbing the player intensely and utterly. It is an activity connected with no material interest, and no profit can be gained by it. It proceeds within its own proper boundaries of time and space according to fixed rules and in an orderly manner." What makes the existing theories different is the overall view of play within other categories of life. In this sense, the most interesting seems to be Eugen Fink's view that defines play as the symbol of the world.

Fink (1993) argument is as follows: play takes place in real time and real space, uses real objects and real people get involved in it.All these variables, no matter their value in the real world, may also become something else while being a part of play. Play assigns them a new meaning. Thus, players are not only real people with a specific personality, but they also have to play a certain role, have certain abilities or act in a certain manner that might not be natural to them in the real world (e.g. a goalkeeper). Also the space within which play occurs is real physical space, though this real space may not coincide with the scenery of the playful activity (e.g. "out" in ball games). The time of play 
occurs on the one hand in real time, when we can miss other events going on in our lives, but it also develops its own imaginary plot that, again, may not coincide with our ordinary timing. Thus, we can conclude that the world of play does not consist of players, objects, scenery, own timing etc. These things do not create the world of play, it is exactly the other way round. It is the world of play that gives these ordinary things their specific, new, "playful" meaning.

\section{PLAYER'S ROLE IN PLAY}

According to Fink (1993), play in this sense is a symbol of the world. Just as play is not the sum of its of players, playing tools and playing sceneries, the world is not the sumof real people and real objects either. It is rather their background, or as Fink says, their horizon. But as Fink also notes, we ordinary people submerged in our ordinary everyday lives, tend to think there is no deeper, more profound foundation for the world. Our naïve attitude tends to see only what we hold in our hands, what is set before us - things we do, fulfill and complete. It is customary in human life to see only objects and omit the context within which they emerge. But play has its own logic that does not coincide with the logic of the world. And that is why, according to Fink (1968), play reminds us that our perception of everyday objects is relative and fragmental. Play is characterized by autonomous, self-sufficient meaning that develops outside of the utility of the everyday. What matters in play is the pure presence, we may even say timeless presence that contrasts radically with the restless dynamism of our lives. Fink believes play is the true oasis of happiness because it does not pursue any concrete (relative or fragmental) happiness.

However, there is an interesting paradox regarding the player's role in play. Gadamer (2011) expresses it like this: "The player knows very well what play is, and that what he is doing is 'only a game'; but he does not know what exactly he 'knows' in knowing that." Thus, the player somehow "knows" what play is - that it is nothing serious. That is actually the reason why he plays. He would not play if it was just one more obligation, one more burden. He also somehow "knows", as Gadamer adds, that play only fulfills its purpose if one takes it absolutely seriously. He somehow irrationally feels these two sides of the coin - the lightness as well as the seriousness (or as Gadamer says, even sacredness). But as Huizinga pointed out back in 1936, a player's behaviour may easily lead to so called puerilism. This refers on the one hand to: "activities of a professedly serious nature and universally regarded as serious (that) come to be permeated with the spirit of play and to bear all the characteristics of play; on the other, activities admittedly of a play(ful) character (that) come to lose the true quality of play because of the manner in which they are carried on". Thus, puerilism is the kind of behaviour that comes from mixing up the ease and the seriousness of play. It is the behaviour of a bored child, 
a football hooligan, a corrupted player or a grown-up addicted to a smartphone. What happens in puerilism is that play loses its lightness, as well as its seriousness, and becomes merely an empty shell.

\section{WHAT MAKES PIPPI THE PLAYER PAR EXCELLENCE}

Pippi Longstocking dwells in the world of play without being bored, without behaving childishly. Her play is simply and utterly childlike, but not childish. She dwells in the timelessness of play, taking it as seriously as the make-believe space and time require. On the other hand, when there is something serious going on, like a child that needs to be protected or people in an emergency on the top floor of a house on fire, she acts surprisingly maturely. This is because Lindgren did realize and could express the merits, as well as the failings of play, very well and that she understood its power in the hands of a child.

Thus, we need to understand that play is only play, it is not philosophy, nor education. Play is only powerful when we are not trying to do anything else. It is fully optional and it is done purely for fun. It stands outside of the world of obligations. The only thing it requires from the player is his presence, to be fully present there, to take the process seriously. If a player does not fulfill this requirement, play becomes an empty shell for him. If he does, we are convinced, and the space in which it occurs turns into the ground for his own freedom. In such fully focused presence, it just becomes him and the world face to face. Both freed from any concepts like politics, religion, ideologies, social roles or expectations. Both freed from duties and utility.

Piper (1992), a philosopher contemplating the concept of leisure time, distinguished between two Latin terms: artes serviles and artes liberales. While artes serviles cover activities that are useful and something useful comes out of them, thus they are rather instruments, mediums or means of getting something done. Artes liberales indicate activites that have a purpose or goal in themselves. Paideia - as the building stone of philosophy - had purpose in itself. Schólé - what European schooling is based on - has purpose in itself. We believe play - when being taken seriously in its lightness - also belongs to this category.

\section{PRAISE OF INUTILITY}

The mantra of contemporary society seems to be: more competitive, more productive, more useful. It has different consequences in different areas of living. Nevertheless, education seems to be affected within its deepest structures. Does schooling need to be useful? Is the demand for the practical application of education eligible? What is the role of creative and inutile play in education? 
In our article we have tried to show that play has a crucial role in education. But not primarily as a methodological tool. Rather as the breach in all practicalities. Play frees us from all that we must, need to or have to do. It gives us a true break. It creates a hiatus where one can simply be. Be present, be involved, be true to oneself. Fink (1968) calls play an oasis of happiness. Happiness arises from the very fact that play time does not pursue any specific happiness. Happiness is simply the state of one's actual being.

Playing is not a serious mind activity. It is not philosophy. It is not science that aims to improve the life condition of human beings. Play is based on make-believe. One pretends to be someone else, someone who is not in real life. Play does not pretend to be real life. If it does, it is not fruitful play, but rather a false sophistication. The true acquisition of play is in its ability to give a break from real life. It gives us a break and it returns us - refreshed and recreated. A good form of play always lets us know the border between make-believe and real life, it never mixes one and the other.

Thus, play in this sense is thoroughly inutile. It is inutile because it does not aim at achieving any specific turn in one's life. It just creates space for any change that is to come, that is substantive for a concrete human being. It provides space for a change in one's soul. It is a tool that makes it possible. In this break from real life and the possibility of a transition in one's soul, is where education (paideia), philosophy and play are deeply connected as the background for creativity as we defined it at the beginning of the article.

\section{REFERENCES}

Amabile, T. M. (1996). Creativity in context. Boulder, CO: Westview Press.

Caillois, R. (1998). Hry a lidé: maska a závrat'. [Games and People: mask and vertigo]. Praha: Nakladatelství Studia Ypsilon.

Fink, E. (1968). The Oasis of Happiness: Towards an Ontology of Play. Yale French Studies. Fink, E. (1993). Hra jako symbol světa. [Play as the Symbol of the World]. Praha: Český spisovatel.

Gaare, J. Sjaastad, O. (2005). Pipi a Sókratés: filosofická hostina ve vile Vilekule. [Pippi and Socrates: philosophical feast in villa Vilekula].Praha: Knižní klub.

Gadamer, H-G. (2011). Pravda a metoda II: dodatky, rejstřiky. [The Truth and the Method II: additions and registers]. Praha: Triáda.

Huizinga, J. (1936). In the Shadow of Tomorrow: a diagnosis of the spiritual ills of our time. New York: W. W. Norton and Co. 
Huizinga, J. (1980). Homo Ludens: a study of the play element in culture. London: Routledge \& Kegan Paul Ltd.

Chvatík, I. (2011). The Responsibility of the "Shaken": Jan Patočka and his "Care for the Soul" in the "Post-European" World. In I. Chvatík, E. Abrams (Eds.) Jan Patočka and the heritage of phenomenology: centenary papers. (pp 263-280). Dordrecht: Springer.

Komenský, J.A. et al. (1966). De rerum humanarum emendatione consultatio catholica [General Consultation on an Improvement of All Things Human]. Praha: Academia.

Opravilová, E. (2016). Školka je laboratoří lidských vztahů. [Preschool as a Laboratory of Human Relationships]. In Informatorium 3-8, 10/2007. Retrieved December 13, 2016 from http://www.zkola.cz/rodice/vybirameskolu/materskeskoly/Stranky/Školka-jelaboratoří-lidských-vztahů.aspx http://www.zkola.cz/rodice/vybirameskolu/ materskeskoly/Stranky/\%C5\%A0kolka-je-laborato\%C5\%99\%C3\%AD-lidsk\%C3\% BDch-vztah\%C5\%AF.aspx

Pieper, J. (1992). Volný čas, vzdělání, moudrost. [Leisure time, Education, Wisdom].Praha: Křest’anská akademie.

Palouš, R. (2004). Ars docendi. [The Art of Teaching].Praha: Karolinum.

Palouš, R. (2010). Filosofická reflexe několika pojmů školské pedagogiky. [Philosophical Reflection on Several Terms of School Pedagogy].Praha: Karolinum.

Patočka, J. (1996). Péče o duši: soubor statí a přednášek o postavení člověka ve světě a $v$ dějinách. I, Stati z let 1929-1952. [The Care for the Toul: collection of essays and lectures on human's place in the world and in history l., Essays from the years 19291952.] Praha: OIKOYMENH.

Patočka, J. (1999). Péče o duši: soubor statí a přednášek o postavení člověka ve světě a v dějinách. II, Stati z let 1970-1977. [The Care for the Soul: collection of essays and lectures on human's place in the world and in history II., Essays from the years 19701977]. Praha: OIKOYMENH.

Patočka, J. (2002). Péče o duši: soubor statí a přednášek o postavení člověka ve světě a $v$ dějinách. III, Kacířské eseje o filosofii dějin. [The Care for the Soul: collection of essays and lectures on human's place in the world and in history III., Heretic essays on philosophy of history]. Praha: OIKOYMENH.

Patočka, J. (1997). Komeniologické studie: soubor textů o J.A. Komenském. [Commeniological Studie: collection of essays on J.A.Commenius]. Praha: OIKOYMENH. 
Patočka, J. (1997). Filosofie výchovy. [Philosophy of Education].Praha: Pedagogická fa-

kulta Univerzity Karlovy. Studia paedagogica: vědecký bulletin Pedagogické fakulty Univerzity Karlovy v Praze; č. 18.

Platón. (2014). Ústava. [Republic].Praha: OIKOYMENH. Platónovy dialogy; sv. 18.

Corresponding author at: Klára Pirklová, Martinov 233, 27713 Záryby, Czech Republic, E-mail: klara.pirklova@ seznam.cz 